\title{
Nonword Production Performance According to Vocal Rehearsal Condition in Children with Language Delay
}

\author{
Seulki Lee, Dongsun Yim \\ Department of Communication Disorders, Ewha Womans University, Seoul, Korea
}

Correspondence: Dongsun Yim, PhD Department of Communication Disorders, Ewha Womans University, 52 Ewhayeodae-gil, Seodamun-gu, Seoul 03760, Korea

Tel: $+82-2-3277-6720$

Fax: $+82-2-3277-2122$

E-mail: sunyim@ewha.ac.kr

Received: April 9, 2017

Revised: May 14, 2017

Accepted: May 25, 2017

This work is based on the master's thesis of the first author.

\begin{abstract}
Objectives: The purpose of this study was to investigate the rehearsal method of improving phonological short-term memory ability by examining the performance of nonword production according to vocal rehearsal condition in children with language delay and normal language. Methods: The participants in this study were 17 children with language delay (LD group) and 17 children with normal language (NL group). The study utilized nonwords and abstract pictures with 3 different conditions of rehearsal suppression, vocal rehearsal 5 times, and vocal rehearsal 10 times. During the vocal rehearsal, the children had to rehearse and then produce the nonword. Results: The results of this study are as follows. First, the LD group showed significantly lower performance in the nonword production in rehearsal suppression condition and the vocal rehearsal 10 times condition than the NL group. Second, the LD group had different error types according to the vocal rehearsal condition, but NL group had constant error types regardless of the conditions. Third, both groups showed a correlation between vocabulary and the performance of nonword production. Conclusion: The performance of nonword production of children with language delay is lower than that of children with normal language, which means that children with language delay have a lower phonological short-term memory capacity. In addition, rehearsal has a positive effect on phonological short-term memory improvement, and it implies an association between phonological short-term memory ability and vocabulary.
\end{abstract}

Keywords: Language delay, Vocal rehearsal, Nonword, Phonological short-term memory
아동은 성인에 비해 언어에 대한 소리 구조(sound structure), 의 미, 철자에 대한 경험이 부족하기 때문에(Gathercole \& Baddeley, 1993 ) 언어 습득 및 발달을 위해 수많은 언어자극을 모방하고 기억 하는 과정의 반복을 필요로 한다. 이러한 과정에서 음운적 정보를 저장하는 음운기억은 음운 정보를 부호화(encoding)하여 작업기 억이나 단기기억에 임시 저장하고 이를 유지하는 능력으로 어휘 발 달과 밀접한 관련이 있다고 보고된다(Stanovich \& Siegel, 1994; Swanson \& Berninger, 1995).

언어발달지연 아동은 어휘 발달 과정의 대부분 측면에서 전반적인 지체 및 결함을 보이는데(Leonard, 1998), 이러한 결함과 음운 단기 기억 즉 음운기억 체계의 결함 사이의 밀접한 관련은 많은 연구를 통해 밝혀졌다(Alt \& Spaulding, 2011; Kim \& Yim, 2012). Baddeley
(1986)의 작업기억 모델(working memory model)은 음운 단기기억 과 어휘 학습의 관계를 가장 대표적으로 설명하는데, 어휘 학습 결 함의 원인을 음운 단기기억과 통용되는 음운루프(phonological loop)의 결함과 관련하여 설명한다(Alt, 2011; Yim, Yang, \& Kim, 2015). 음운루프는 음운 저장소(phonological store)와 조음시연장 치(articulatory rehearsal system)를 하위요소로 가지고 있으며, 음 운 저장소에 일시적으로 저장되는 음운 정보의 삭제를 방지하기 위 해 시연의 중요성이 강조되어 왔다(Henry, 1991).

음운 단기기억은 기존에 가지고 있는 장기기억의 지식이 과제 수 행에 미치는 영향을 방지한 상태에서 측정되어야 하기 때문에 비단 어를 활용하는 경우가 빈번하며(Baddeley, Gathercole, \& Papagno, 1998), 지금까지 비단어 따라말하기 수행 능력을 통해 언어발달지 
연 아동의 음운 단기기억의 결함을 밝힌 연구가 활발하게 진행되 고 있다(Hulme \& Brown, 1993; Rispens \& Baker, 2012). 언어발달 지연 아동은 음운 단기기억의 결함으로 인해 음운 정보의 수용 능 력이 제한되고 음운 정보의 삭제 속도가 일반 아동에 비해 빠른 것 으로 알려져 있는데(Conti-Ramsden, Botting, \& Faragher, 2001) 이런 현상은 음운 정보의 시연(rehearsal)을 통해 방지할 수 있다 (Baddeley, 1986).

시연은 제시된 정보를 있는 그대로 기억해야 할 때 유용한 방법 으로써(Park \& Choi, 2007) 새로운 구어 자극이 투입될 때 기억해 야 할 정보를 머릿속으로 되풀이하는(Baddeley, 1986, 2000) 내현 적 시연(subvocal rehearsal)과 나중에 회상해 낼 것을 생각하고 기 억할 정보를 미리 말로 되풀이 하는(Kim, 1997) 외현적 시연(vocal rehearsal)으로 구분한다. 기존 연구에서 시연은 7세가 되어야 자발 적으로 사용할 수 있다고 알려져 왔지만(Cowan \& Kail, 1996; Gathercole \& Adams, 1993) 최근에는 7세 미만의 아동이 시연을 자발적 으로 사용할 수 있으며, 시연 훈련이 적용 가능하다는 연구가 진행 되고 있다(DeMarie, Miller, Ferron, \& Cunningham, 2004; Fletcher \& Bray, 1996; Park \& Choi, 2007). 기억 체계는 어떠한 정보든 회 상하고 주목하는 전략을 통해 정보가 기억에서 사라지는 과정을 보완하는데 언어 정보의 경우에는 시연을 통해 정보가 단기기억을 거쳐 장기기억에 저장되는 과정에서 변질되거나 삭제되는 것을 방 지한다(Cowan, 1992). 즉 아동의 어휘 학습은 음운 단기기억에 낯 선 음운 정보를 저장하고 시연을 활용하여 음운 정보를 학습하고 음운 규칙을 파악하는 과정을 통해 이뤄지는 것이다(Martin \& Ellis, 2012). 따라서 시연은 음운 단기기억 능력과 밀접한 관련이 있으 며 나아가 어휘 학습에도 적지 않은 영향을 주어 언어 발달 과정에 서 중요한 역할을 담당하고 있다고 할 수 있다.

시연 방법을 스스로 인식하고 시연의 효과 및 가치를 깨닫게 되 면 대부분 시연을 자발적으로 사용하게 되는데(Oxley \& Norris, 2000) 언어발달지연 아동은 시연을 자발적으로 사용하지 못하거 나 비효과적인 시연을 시도하기 때문에 음운 단기기억에 결함이 나 타난다고 볼 수 있다(Alt \& Spaulding, 2011). 선행연구(Montgomery \& Evans, 2009)에서 언어발달지연 아동의 언어 처리 능력의 속 도와 음운 단기기억 수행 능력 사이의 연관성을 밝혀왔으며, 음운 단기기억과 시연의 관계에 대한 연구도 활발하게 진행되어 왔다 (Ellis, 1970; Sweet et al., 2010). 즉, 언어발달지연 아동은 외현적 시 연을 사용하는 능력과 시연을 통한 기억 유지 능력이 결여되어 있 는 것이다. 이러한 문제점과 관련하여 시연을 통한 음운 단기기억 능력의 향상과 시연 훈련의 효과에 대한 연구는 꾸준히 진행되고 있다. 어휘 학습 능력을 음운 단기기억과 연결시켜 파악하고 단기기
억 능력을 향상시킬 수 있는 가능성을 연구한 결과, 시연 전략을 사 용하였을 때 가장 높은 단기기억 능력의 향상이 나타났으며(Jeon, 1991; Kim, 2012), 낯선 음운 정보의 학습 과정에서 시연 훈련은 필 수 요소이자 가장 효과적인 학습 방법으로 알려져 있다(Beaton,

Gruneberg, Hyde, Shufflebottom, \& Sykes, 2005; Ellis \& Beaton, 1993). Turley-Ames와 Whitfield (2003)는 시연은 정상 아동과 언 어발달지연 아동 모두에게 학습을 가장 용이하게 유도하는 최적의 방법이라고 보고하기도 하였다. 이 연구는 시연이 다른 기억 전략 에 비하여 적용이 간단하고 전략 자체가 기억 용량을 많이 사용하 지 않으며, 짧은 지시만으로도 기억할 정보에 집중할 수 있는 효과 적인 전략이라고 설명하고 있다. 결과적으로 시연은 전반적인 인지 기능의 결함을 가지고 있는 아동에게도 훈련시킬 수 있으며, 이를 통해 음운 단기기억 능력의 향상을 기대할 수 있을 것으로 보인다. 따라서 언어발달지연 아동에게 적용할 수 있는 시연 방법을 연구 하여 언어발달지연 아동이 올바른 시연을 자발적으로 사용할 수 있게 된다면 음운 정보를 활성화하여 정보의 빠른 삭제를 막을 수 있을 것으로 예상된다.

아동의 시연 과정을 연구하는 과정에서 내현적 시연은 정확한 횟수나 시간의 측정이 불가능하기 때문에 사용 여부를 대상자에 게 직접 묻는 방법(Baddeley, Lewis, \& Vallar, 1984; Park \& Choi, 2007)을 사용하는데 이러한 방법은 아동이 어릴 경우, 시연 여부와 횟수를 정확하게 파악하기 어렵고 다른 기억 책략의 사용과 혼합 되는 것을 통제하기 어렵다. 반면, 외현적 시연은 시연 여부와 횟수 의 파악이 용이하고 조절이 가능하다는 장점을 가지고 있어 목표 어휘 또는 문장을 되풀이하여 말하는 연습을 통해 훈련이 가능하 다. 따라서 Baddeley (1986)의 작업기억 모델에서 말하는 시연을 토 대로 외현적 시연을 조건화하여 음운 정보 산출 능력을 살펴보고 언어발달지연 아동의 음운 단기기억 능력을 향상시킬 수 있는 방안 을 모색해볼 필요성이 있다.

외현적 시연에 대한 연구를 살펴보면 외현적 시연의 훈련에 따른 음운 단기기억 능력의 향상을 다룬 연구(Keeney, Cannizzo, \& Flavell, 1967; Kim, 1997)와 외현적 시연 훈련의 적절성을 다룬 연구 (Turley-Ames \& Whitfield, 2003)는 진행되어 왔지만 시연 여부에 대한 조건을 설정하지 않고 자발적인 시연 사용 여부에 대한 연구 가 진행되거나(Alt \& Spaulding, 2011; Park \& Choi, 2007; Torgesen \& Goldman, 1977) 시연의 횟수에 대한 통제가 이뤄지지 않았다.

따라서 본 연구는 언어발달지연 아동과 일반 아동을 대상으로 외현적 시연 조건에 대한 음운 정보의 유지 능력의 차이점과 음운 단기기억 능력의 향상 효과를 알아보도록 하였다. 외현적 시연을 조건화하여 낮선 음운 정보에 대한 산출 능력을 음소 정확도와 오 
류유형으로 비교분석하여 구체화하였다. 이러한 연구에 따른 결과 는 언어발달지연 아동의 음운 단기기억 결함을 해결하기 위해 적용 할 수 있는 적절한 시연 방법과 정도를 파악하는데 도움이 되어 임 상적 시사점이 있을 것으로 예상된다.

이에 대한 본 연구의 세부 연구 질문은 다음과 같다.

첫째, 집단 간(언어발달지연 아동, 일반 아동) 외현적 시연 조건에 대한 비단어 산출수행력에 유의한 차이가 있는가?

둘째, 집단 간(언어발달지연 아동, 일반 아동) 외현적 시연 조건에 대한 비단어 산출의 오류유형에 유의한 차이가 있는가?

셋째, 수용 및 표현어휘력은 외현적 시연 조건에 대한 비단어 산 출 수행력과 유의한 상관관계가 있는가?

\section{연구방법}

\section{연구대상}

본 연구는 서울 및 경기 지역에 거주하는 만 5-7세 언어발달지연 아동 17 명(남 10 명, 여 7 명), 그리고 생활연령과 성별을 일치시킨 일 반 아동 17 명(남 10명, 여 7명), 총 34 명을 대상으로 하였다.

Leonard (1998)는 표준화된 언어검사에서 -1.25 표준편차(SD) 미만에 속하며 표준화된 지능 검사에서 비언어성 지능이 $-1 \mathrm{SD}$ 이 상에 속하는 경우를 단순언어장애로 진단하였다. 본 연구에서는 단순언어장애 진단 기준을 동일하게 사용하되 아동의 언어 능력을 대표적으로 나타내는 언어 검사인 수용-표현어휘력검사(REVT:

Kim, Hong, Kim, Jang, \& Lee, 2009)로 언어 능력을 파악하여 이를 언어발달지연으로 칭하였다.

본 연구에 참여한 언어발달지연 아동은 (1) 부모 또는 교사에 의 해 지적 능력은 정상 범주이나 언어 능력에 부족함을 보이는 것으 로 보고되고, (2) 수용·표현어휘력검사(REVT: Kim et al., 2009) 결 과 수용어휘력 또는 표현어휘력 중 하나 혹은 그 이상이 자신의 생 활연령 기준에서 -2 SD 미만이며, (3) 카우프만 아동용 지능검사 (K-ABC; Moon \& Byun, 2003)의 비언어성 지능점수가 85점(-1 SD) 이상이며, (4) 기타 행동, 정서, 시각 및 청각 등의 감각장애, 자폐나 $\mathrm{ADHD}$ 등의 신경학적 증상 관련 장애의 이력이 없고 구강 구조 및 운동 능력에 결함을 보이지 않는 아동으로 선정하였다.

본 연구에 참여한 일반 아동은 (1) 부모 또는 교사에 의해 지적 능 력 및 언어 능력에 결함을 보이지 않는 것으로 보고되고, (2) 수용. 표 어휘력검사(REVT: Kim et al., 2009) 결과 수용 및 표현어휘력 모두 정상 발달 범주(-1 SD 이상)에 해당하며, (3) 카우프만 아동용 지능검사(K-ABC; Moon \& Byun, 2003)의 비언어성 지능점수가 85점(-1 SD) 이상이며, (4) 기타 행동, 정서, 시각 및 청각 등의 감각
Table 1. Participants' characteristics

\begin{tabular}{lcccc}
\hline & $L D(N=17)$ & $N L(N=17)$ & $t$ & $p$-value \\
\hline Age (mo) & $80.24(9.087)$ & $77.76(6.924)$ & -.892 & .379 \\
Nonverbal IQ & $101.59(11.630)$ & $104.06(6.995)$ & .751 & .460 \\
REVT-R & $60.82(12.396)$ & $81.47(16.508)$ & $4.124^{* *}$ & .000 \\
REVT-E & $68.53(18.087)$ & $83.94(10.674)$ & $3.026^{*}$ & .005
\end{tabular}

Values are presented as mean (SD).

$\mathrm{LD}=$ children with language delay; $\mathrm{NL}=$ children with normal language; $\mathrm{REVT}=$ Receptive \& Expressive Vocabulary Test (Kim, Hong, Kim, Jang, \& Lee, 2009).

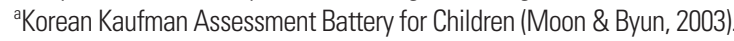

${ }^{*} p<.05,{ }^{* *} p<.001$.

장애, 자폐나 $\mathrm{ADHD}$ 등의 신경학적 증상 관련 장애의 이력이 없고 구강 구조 및 운동 능력에 결함을 보이지 않는 아동으로 선정하였다.

언어발달지연 아동 집단의 평균 생활연령은 80.24 개월 $(\mathrm{SD}=9.09)$, 일반 아동 집단의 평균 생활연령은 77.76 개월 $(\mathrm{SD}=6.924)$ 이었다. 언어발달지연 아동 집단의 동작성 지능 평균은 101.59 점 $(\mathrm{SD}=11.63)$ 이고, 일반 아동 집단의 동작성 지능 평균은 104.06점 $(\mathrm{SD}=7.0)$ 이 었다. 또한 언어발달지연 아동 집단의 수용어휘력은 60.82 점(SD= $12.4)$, 표현어휘력은 68.53점( $\mathrm{SD}=18.09)$ 이고 일반 아동 집단의 수용 어휘력은 81.47 점( $\mathrm{SD}=16.51)$, 표현어휘력은 83.94 점 $(\mathrm{SD}=10.67)$ 이다.

두 집단의 통제가 잘 이루어졌는지 확인하기 위하여 독립표본 $t$-검정(independent $t$-test)을 실시한 결과, 두 집단의 생활연령 $(t=$ -.892, $p>$.05)과 동작성 지능 점수 $(t=.751, p>$.05)에서 통계적으로 유의한 차이가 없었다. 그리고 집단 간 수용어휘력 점수 $(t=4.124$, $p<.001)$ 와 표현어휘력 점수 $(t=3.026, p<.05)$ 에서는 통계적으로 유의한 차이가 나타났다. 두 집단의 생활연령, 비언어성 지능, 수용 및 표현어휘력 점수의 평균 및 표준편차는 Table 1 에 제시하였다.

\section{연구도구}

비단어 선정

본 연구는 어휘 저장소에 이미 저장되어 있는 단어의 음운 형태 및 규칙의 영향을 받지 않고 온전히 음운 단기기억 능력을 활용하 여 새로운 음운 표상을 형성하고 산출하는 능력을 측정하기 위해 실제 단어와 유사성이 낮은 비단어를 활용하였다. 또한 선행연구 (Kan, Sadagopan, Janich, \& Andrade, 2014)에서 성인을 대상으로 2-3음절의 비단어를 활용한 것을 바탕으로 본 연구에서는 시연 진 행 시간이 10 초라는 점과 예비연구 결과 5-6음절의 비단어를 본 연 구의 과제에 포함하기에는 아동에게 무리가 있었다는 점을 고려하 여 2-4음절로 제한하였다. 선행연구(Oh \& Yim, 2013)에서 사용된 비단어 중, 2-4음절 비단어 24개를 모두 추출하여 수정 및 보완하 였다. 비단어 24 개를 활용하여 연구 대상자로 참여하지 않은 생활 
연령 5-7세 사이의 일반 아동 5명에게 비단어 따라 말하기를 실시 하였다. 24 개의 비단어 중, 3 명 이상의 아동이 발음에 어려움을 보 인 4 개의 비단어를 제외하여 비단어의 난이도롤 조정하였다. 4 개 의 비단어를 제외하고 남은 20 개의 비단어 중, 음절구조와 각각의 자모음 사용 빈도를 고려하여 총 18 개의 비단어를 선정하였다. 사 용된 자음은 'ᄀ, ᄂ, ᄃ, ㄹ, ㅁ, ㅂ, ㅇ, ㅈ, ㄱ, ㅌ, 프, ㄱ, , 뻐'로

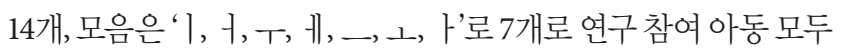
가 산출 가능한 말소리이다. 각 음절길이마다 비단어 문항 수는 6 개로 구성되어 있으며, 각 음절길이 당 2 개씩 분류되어 3 가지 외현 적 시연 조건에 각각 적용되었다(Appendix 1).

\section{그림 선정}

본 연구는 선행연구(Alt \& Spaulding, 2011; Kan et al., 2014)에 따라 비단어와 추상적 그림을 연결 지어 아동의 음운 단기기억 능 력을 알아보고자 하였다. 여기에서 추상적 그림은 실존하는 사물 과 유사성이 낮고 명칭을 붙이기 어려우며, 처음 보는 그림을 뜻한 다. 추상적 그림은 Horst와 Hout (2016)의 Novel Object \& Unusual Name (NOUN) Database를 바탕으로 18개를 선정하였다. 선정된 18 개의 추상적 그림은 NOUN Database에서 제시하는 Familiarity scores (F) 및 Name-Ability scores (N)가 모두 평균 이하이다. 추상 적 그림은 비단어와 각각 쌍을 이루어 본 연구에서 사용되었다. 추 상적 그림의 F값과 N값은 Appendix 2에 제시하였다.

\section{예비실험}

실험 과제의 방법을 조정하고 원활한 진행 과정을 점검하기 위해 생활연령 만 5-7세에 해당하는 일반 아동 5명, 언어발달지연 아동 5 명을 대상으로 예비실험을 실시하였다. 과제 진행 시 외현적 시연 횟수에 대한 설정이 필수적이기 때문에 10 초 동안 실시할 수 있는 외현적 시연 횟수를 조절하였다. Kan 등(2014)에서 성인을 대상으 로 시연 횟수를 3 배로 조정한 것을 바탕으로 아동에게 시연 횟수를 4 회, 12 회로 지정 후 과제를 진행하였으나 시연 수행에 어려움을 보 여 본 연구는 시연 횟수를 2 배 차이로 조정하였다. 아동은 성인에 비하여 구강 움직임이 수월하지 않고 말속도가 느리기 때문에(Sadagopan \& Smith, 2008) 이러한 어려움이 나타난 것으로 보인다. 또 한 Baddeley (1986)의 작업기억 모델에 의하면 청각적으로 제시된 음운 정보는 음운표상(phonological representation)으로 1.5-2초 간 저장되고 지속적인 시연이 반복되지 않으면 삭제되기 때문에 10 초간 실시할 수 있는 최소의 시연 횟수를 5 회로 지정하였다. 결과적 으로 외현적 시연 조건은 5 회와 10 회로 지정하였고 아동이 외현적 시연을 5 회와 10 회 모두 실시할 수 있는지 확인하였다. 예비실험 결
과, 모든 아동이 주어진 시간 동안 외현적 시연을 실시할 수 있었고 아동이 시연 방법을 좀 더 정확하게 파악할 수 있도록 연습 문항을 추가하였다.

\section{외현적 시연 조건 설정}

언어발달지연 아동과 일반 아동을 대상으로 외현적 시연 조건에 대한 비단어 산출 수행력을 통해 음운 단기기억의 능력을 알아보 도록 하였다. 외현적 시연 조건은 총 3가지 조건(시연 억제, 외현적 시연 5 회, 외현적 시연 10 회)으로 구성되었고 각 조건의 문항은 6 개 로, 총 검사 문항은 18 개이다. 각 조건은 아동마다 균형 배치하여 제 시되었다. 외현적 시연을 실시하는 시간은 Alt와 Spaulding (2011) 의 연구에 따라 10 초로 통제하였으며, 예비연구를 진행하여 시간 내에 아동이 실시할 수 있는 수준으로 외현적 시연의 횟수를 조정 하였다.

각 외현적 시연 조건은 다음과 같다. 시연 억제 조건은 선행연구 에서 실시한 시연 억제 방법들(Alloway, Kerr, \& Langheinrich, 2010;

Papagno, Valentine, \& Baddeley, 1991; Soto \& Humphreys, 2008) 을 바탕으로 만 5-7세 아동이 모두 알 수 있는 색깔의 이름을 활용 하였고 외현적 시연 5 회 조건과 외현적 시연 10 회 조건은 비단어 소 리 자극이 제시된 후, 10 초간 소리 자극을 기억하여 외현적 시연을 실시하도록 하였다.

외현적 시연을 실시하는 과정에서 아동이 비단어 소리 자극을 부정확하게 발음하거나 발음을 틀리거나 혹은 아동의 음성이 작아 도 검사자가 임의로 아동의 시연을 수정하거나 모델링하지 않는다. 시연은 본래 따라 말하기와 달리 자신이 들은 소리를 기억하기 위 해 읖조리는 기억 전략이기 때문에 정확한 발음이 강요되지 않고 외부에서 시연을 수정할 경우 아동의 시연 능력에 의한 음운 단기 기억 능력을 정확하게 파악하지 못할 가능성이 크다(Huttenlocher \& Burke, 1976). 또한 반드시 언어 정보를 그대로 시연하지 않고 부 분적으로 시연하거나 혹은 시연 과정에서 약간의 오류가 발생한다 해도 언어 정보를 이해 및 표현하는 과정에서 긍정적인 효과를 준 다는 연구결과(Baddeley, 2000)를 기반으로 한다.

\section{연구절차}

검사는 검사자와 아동이 일대일로 소음이 차단된 공간에서 개별 적으로 실시하였다. 각 외현적 시연 조건의 순서는 아동마다 무작 위로 제시되었고 각 조건을 실시하기 전에 2 개의 연습 문항을 통하 여 아동이 과제에 대해 정확하게 숙지할 수 있도록 한 후, 본 검사를 실시하였다. 외현적 시연 조건이 시연의 횟수이기 때문에 아동이 각 조건에서 말 속도를 일정하게 유지하면서 시연 횟수를 지킬 수 
있도록 훈련시켰다. 만약 아동이 검사에 응하려 하지 않거나 연습 문항을 이해하지 못할 경우, 검사를 진행하지 않았다. 또한 연습 문 항은 이해하였고 연습 문항 진행 시 시연 조건에 따라 시연을 실시 가능했으나 검사 도중 시연 횟수 및 속도를 따라가지 못하거나 포 기하거나 의도적으로 시연 횟수를 초과하여 실시하는 경우에는 검 사를 중단하였다. 연구 진행 과정에서 일반 아동은 4 명, 언어발달지 연 아동은 6 명이 위와 같은 이유로 검사 진행을 중단하였다. 각 조 건에 대한 검사자의 모델링이나 피드백은 연습 문항에서만 제시하 며 본 과제를 수행할 때는 어떠한 도움도 제공하지 않았다. 본 검사 가 시작되기 전에 검사자는 아동에게 검사 시 제공되는 그림과 소 리 자극은 처음 듣고 처음 보는 자극임을 미리 설명하여 아동이 숙 지할 수 있도록 하였다. 아동은 화면을 통해 추상적 그림을 보면서 그림에 해당하는 비단어 소리 자극을 헤드셋을 사용하여 듣고 각 조건에 따른 외현적 시연 후, 제시되었던 비단어 소리 자극을 산출 하였다.

각 조건의 과제 순서는 연습 문제, 본 문제 순으로 실시되며 구체 적인 절차는 다음과 같다. 시연 억제 조건은 추상적 그림이 제시되 는 동시에 녹음된 음성으로 하나의 비단어가 1 초 간격으로 2 번 제 시된 후, 10 초 동안 시연 억제를 실시하도록 하였다. 추상적 그림 하 단에 5 가지 서로 다른 색깔의 원이 제시되는데 아동은 색깔의 이름 을 말함으로써 시연을 억제하였다. 아동의 주의를 집중시킨 후 검 사자는 "컴퓨터 화면에 처음 보는 그림이 나타나고 그림의 이름이 들릴 거에요. 그림의 이름을 잘 듣고 나서 잠시 후에 그림의 이름을 말하는 거에요. 바로 말하는 게 아니라 그림 아래에 나오는 동그라 미의 색을 말해주고 나서 그 후에 말해야 해요.”라고 지시하였다. 원의 색깔을 말하는 과정은 단순히 시연을 억제하기 위함이므로 이 과정에서 발생하는 오류는 점수에 영향을 미치지 않았다. 시연 억제 과정 후, 0.5 초간 그림이 사라지고 다시 그림이 나타나면 아동 은 들었던 비단어를 산출하였다. 외현적 시연 5 회 조건은 추상적 그 림이 제시되는 동시에 녹음된 음성으로 하나의 비단어가 1 초 간격 으로 2 번 제시된 후, 10 초 동안 2 초 간격으로 외현적 시연을 5 회 실 시하였다. 추상적 그림 하단에 2 초 간격으로 5 개의 불빛이 나타나 며 아동은 불빛이 나타나는 속도와 횟수에 맞춰 외현적 시연을 실 시하였다. 아동의 주의를 집중시킨 후 검사자는 "컴퓨터 화면에 처 음 보는 그림이 나타나고 그림의 이름이 들릴 거에요. 그림의 이름 을 잘 듣고 나서 잠시 후에 그림의 이름을 말하는 거에요. 바로 말 하는 게 아니라 그림 아래에 불빛이 나올 때마다 작은 소리로 그림 의 이름을 연습하고 나서 그 후에 말해야 해요.”라고 지시하였다. 외현적 시연을 5 회 실시한 후, 0.5 초간 그림이 사라지고 다시 그림이 나타나면 아동은 들었던 비단어를 산출하도록 한하였다. 외현적
시연 10 회 조건은 추상적 그림이 제시되는 동시에 녹음된 음성으 로 하나의 비단어가 1 초 간격으로 2 번 제시된 후, 10 초 동안 1 초 간 격으로 외현적 시연을 10 회 실시하였다. 추상적 그림 하단에 1 초 간 격으로 10 개의 불빛이 나타나며 아동은 불빛이 나타나는 속도와 횟수에 맞춰 외현적 시연을 실시하였다. 검사자는 외현적 시연 5 회 조건과 동일하게 아동에게 과제 방법을 지시하였다. 외현적 시연을 10 회 실시한 후, 0.5 초간 그림이 사라지고 다시 그림이 나타나면 아 동은 들었던 비단어를 산출하도록 하였다. 검사자는 연습 문항을 실시하기 전, 아동이 각 조건에 대해 충분히 이해할 수 있도록 직접 시범을 보였고 일정한 속도로 컴퓨터 화면의 동그라미와 불빛에 따 라 시연 억제 및 시연을 실시할 수 있도록 알려주었다.

\section{자료분석}

검사자는 아동의 반응을 검사가 실시되는 동안 반응기록지에 모 두 기록하고 녹음 및 전사하였다. 본 연구에 사용되는 비단어 산출 수행력은 비단어 산출에 대한 음소 정확도(\%)와 오류유형을 통해 측정되었다. 음소 정확도는 적절한 위치에서 정확하게 산출한 음소 수를 산출해야 할 총음소수로 나눈 후 100 을 곱하였다. 아동이 스 스로 수정하여 발화하였을 경우 최종적으로 산출한 것을 반응으 로 처리하였다. 아동이 모른다고 반응하거나 5 초 이상 반응이 없으 면 무반응으로 간주하여 0점으로 처리하였다. 오류유형은 Dell, Schwartz, Martin, Saffran과 Gagnon (1997)의 기준을 바탕으로 음운오류, 비관련 오류, 음절 오류, 왜곡, 무반응으로 분류하여 분 석하였다. 오류유형에 대한 구체적인 정의와 예시는 다음과 같다. 음운 오류는 음절 수는 유지하되, 음소 수준의 오류(음소 생략, 첨 가, 대치 등)를 포함하여 목표 비단어와 음운적으로 유사한 비단어 를 산출한 경우(동일한 위치에 동일한 음소가 $65 \%$ 이상인 경우)를 의미하며 예시는 '니아토'를 '이아토'로 ‘퍼꾸테’를 ‘퍼꾸티'로 산출 하는 경우가 있다. 비관련 오류는 음절 수는 유지하되, 음소 수준의 오류(음소 생략, 첨가, 대치 등)를 포함하여 목표 비단어와 음운적 으로 관련이 적은 다른 단어를 산출한 경우(동일한 위치에 동일한 음소가 $65 \%$ 미만인 경우)를 의미하며 예시는 '머구낭뿔'을 '미그난 다'로 '까다굳’을 ‘따가둗’으로 산출하는 경우가 있다. 음절 오류는 음절 수준의 오류(음절 생략, 첨가)가 발생한 경우(동일한 위치에 동일한 음절이 $50 \%$ 이상 있으나 음절 오류가 발생한 경우)를 의미 하며 예시는 '부에드'를 '부드'로 산출하는 경우가 있다. 왜곡은 음 절 수준의 오류(음절 생략, 첨가)가 발생하여 목표 비단어와 아무 관련이 없는 경미하지 않은 수준의 비단어를 표현한 경우를 의미 하며 예시는 ‘토보가인'을 ‘도라’로 ‘푸가태지'를 ‘뿌때찌’로 산출하 는 경우가 있다. 마지막으로 무반응은 목표 비단어에 대해 아무런 
반응을 하지 않은 경우를 의미한다.

모든 통계적 분석은 SPSS version 24 for Window를 사용하였다. 집단 간 외현적 시연 조건에 대한 비단어 산출 수행력의 차이를 알 아보기 위하여 이원혼합분산분석(two-way mixed ANOVA)을 실 시하였고 각 집단의 어휘력과 외현적 시연 조건에 대한 비단어 산 출 수행력 사이의 상관관계를 알아보기 위하여 Pearson 적률상관 계수분석을 실시하였다.

\section{연구결과}

\section{언어발달지연 아동과 일반 아동의 외현적 시연 조건에 대한 비단어 산출 수행력 비교}

두 집단 간 외현적 시연 조건에 대한 음소 정확도(\%)를 사용하여 비단어 산출 수행력에 차이가 있는지 비교하였다. Table 2에 나타난 바와같이 언어발달지연 아동 집단의 비단어 산출 수행력은 시연 억 제 조건에서 $34.31 \%(\mathrm{SD}=25.40)$, 외현적 시연 5 회 조건에서 $90.24 \%$ $(\mathrm{SD}=9.11)$, 외현적 시연 10 회 조건에서 $82.81 \%(\mathrm{SD}=12.03)$ 로 나타 났고 일반 아동 집단의 비단어 산출 수행력은 시연 억제 조건에서 $61.60 \%(\mathrm{SD}=21.34)$, 외현적 시연 5회 조건에서 $92.81 \%(\mathrm{SD}=6.10)$, 외현적 시연 10 회 조건에서 $94.89 \%(\mathrm{SD}=3.66)$ 로 나타났다. 외현적 시연 조건에 대한 비단어 산출의 수행력은 시연 억제 조건에서 $47.95 \%$ $(\mathrm{SD}=26.93)$, 외현적 시연 5회 조건에서 $91.53 \%(\mathrm{SD}=7.74)$, 외현적 시연 10 회 조건에서 $88.85 \%(\mathrm{SD}=10.68)$ 로 나타났다.

이원혼합분산분석(two-way mixed ANOVA)을 실시한 결과, 집 단에 대한주효과가 통계적으로 유의하였다 $\left(F_{(1,32)}=13.627, p<.05\right)$. 각 집단에서의 비단어 산출 수행력을 살펴보면 일반 아동 집단의 비단어 산출 수행력은 $83.1 \%$ 로 언어발달지연 아동 집단의 비단어 산출 수행력인 $69.12 \%$ 보다 유의하게 높은 비단어 산출 수행력을 보인다는 것을 알 수 있다.

또한 외현적 시연 조건에 대한 주효과도 통계적으로 유의하게 나 타났다 $\left(F_{(1.180,37.753)}=125.226, p<.0001\right)$. 외현적 시연 조건에 따른 차이를 구체적으로 알아보기 위하여 Bonferroni 사후검정을 실시

Table 2. Descriptive statistics of percent accuracy of nonword production by vocal rehearsal condition

\begin{tabular}{llll}
\hline & \multicolumn{1}{c}{ LD } & \multicolumn{1}{c}{ NL } & \multicolumn{1}{c}{ Total } \\
\hline Rehearsal suppression & $34.31(25.40)$ & $61.60(21.34)$ & $47.95(26.93)$ \\
Vocal rehearsal 5 times & $90.24(9.11)$ & $92.81(6.10)$ & $91.53(7.74)$ \\
Vocal rehearsal 10 times & $82.81(12.03)$ & $94.89(3.66)$ & $88.85(10.68)$ \\
\hline
\end{tabular}

Values are presented as mean (SD).

$\mathrm{LD}=$ children with language delay; $\mathrm{NL}=$ children with normal language.
한 결과, 시연 억제 조건(47.95\%)이 외현적 시연 5회 조건(91.53\%) 및 외현적 시연 10 회 조건(88.85\%)보다 유의하게 낮은 비단어 산출수 행력을 나타냈다 $(p<.0001)$. 그룹과 조건 간 이차 상호작용 또한 통 계적으로 유의하게 나타났다 $\left(F_{(1.180,37.753)}=8.159, p<.05\right)$. 이에 따라 LMATRIX SYNTAX와 MMATRIX SYNTAX를 사용하여 상호 작용 대비검정(interaction contrast)을 실시한 결과 시연 억제 조건 과 외현적 시연 5 회 조건에 대한 그룹 간 차이가 통계적으로 유의하 였고 $\left(F_{(1,32)}=10.691, p<.05\right)$ 외현적 시연 5 회 조건과 외현적 시연 10 회 조건에 대한 그룹간차이도 통계적으로 유의하였다 $\left(F_{(1,32)}=13.771\right.$, $p<.05)$. 시연 억제 조건과 외현적 시연 10 회 조건에 대한 그룹 간 차 이 역시 통계적으로 유의하였다 $\left(F_{(1,32)}=4.573, p<.05\right)$. 이에 대한 그래프를 Figure 1에 제시하였다.

\section{언어발달지연 아동과 일반 아동의 외현적 시연 조건에 대한 비단어 산출의 오류유형 비교}

언어발달지연 아동 집단과 일반 아동 집단의 시연 조건에 대한 비단어 산출 시 나타나는 오류를 5 가지 오류유형(음운 오류, 비관 련 오류, 음절 오류, 왜곡, 무반응)으로 나누어 그 차이를 살펴보았 다(Figure 2). 각 집단의 시연 조건에 대한 비단어 산출의 오류유형 을 분석한 결과, 언어발달지연 아동 집단은 시연 억제 조건에서 왜 곡을 가장 많이 보였으며 음운 오류, 무반응, 비관련 오류, 음절 오 류 순으로 오류가 나타났고 외현적 시연 5회 조건에서 음운 오류를 가장 많이 보였으며 그 다음으로 비관련 오류가 나타났고 음절 오 류, 왜곡, 무반응은 나타나지 않았다. 외현적 시연 10회 조건에서는 음운 오류를 가장 많이 보였으며 비관련 오류, 왜곡, 음절 오류, 무 반응 순으로 오류가 나타났다. 일반 아동 집단은 시연 억제 조건에 서 음운 오류를 가장 많이 보였으며 무반응, 비관련 오류, 왜곡, 음 절 오류 순으로 오류가 나타났고 외현적 시연 5회 조건에서 음절 오

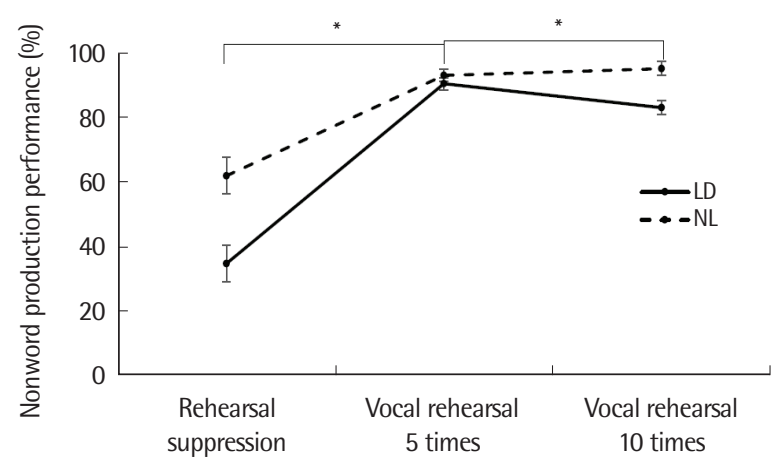

Figure 1. Nonword production performance by vocal rehearsal condition and group.

$\mathrm{LD}=$ children with language delay; $\mathrm{NL}=$ children with normal language ${ }^{*} p<.05$. 


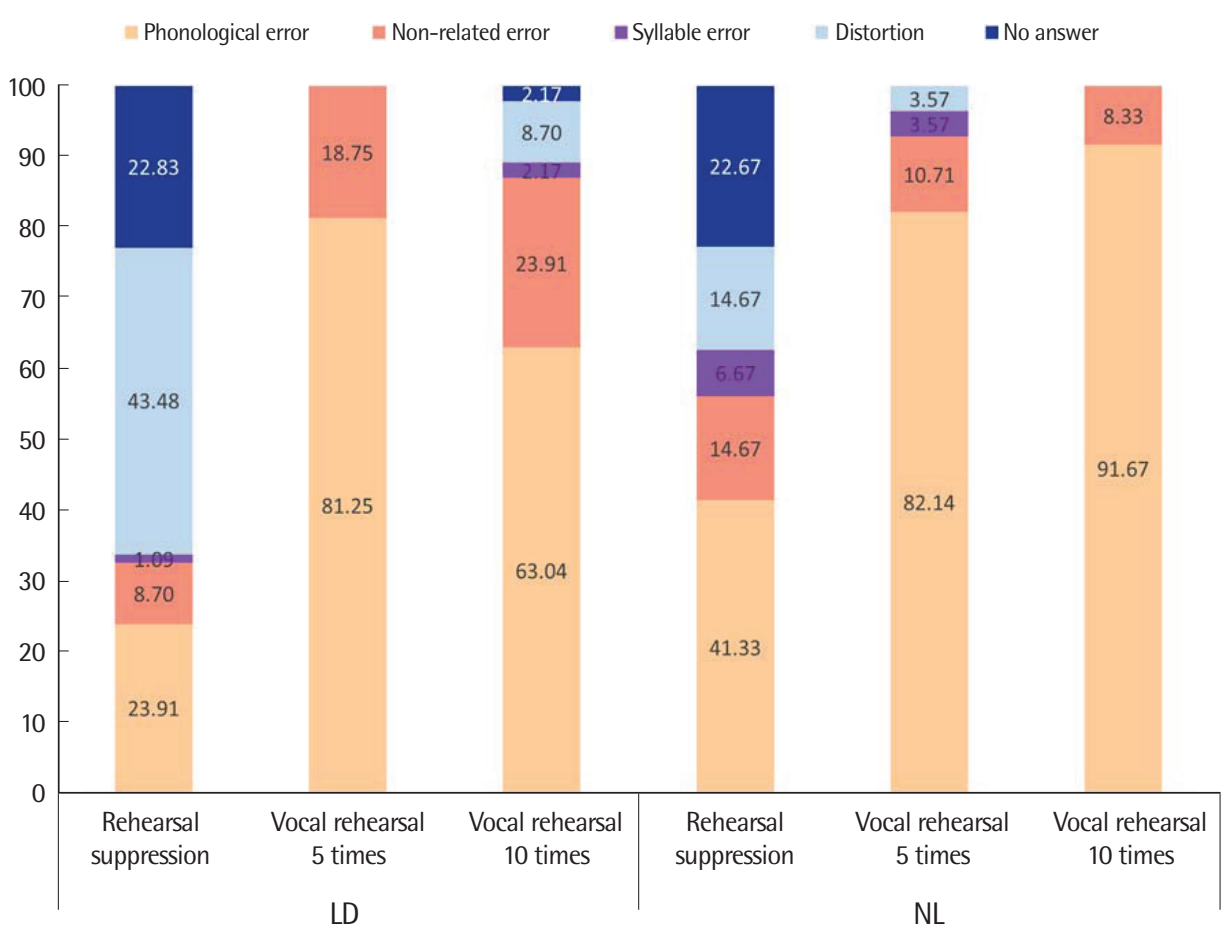

Figure 2. Error types by vocal rehearsal condition of each group.

$\mathrm{LD}=$ children with language delay; $\mathrm{NL}=$ children with normal language.

Table 3. Correlation between variables of children with language delay

\begin{tabular}{lcccc}
\hline & REVT-R & REVT-E & $\begin{array}{c}\text { Rehearsal } \\
\text { suppression }\end{array}$ & $\begin{array}{c}\text { Vocal } \\
\text { rehearsal } \\
5 \text { times }\end{array}$ \\
\hline REVT-E & $.799^{* *}$ & - & - & - \\
Rehearsal suppression & $.489^{*}$ & .409 & - & - \\
Vocal rehearsal 5 times & $.619^{* *}$ & $.661^{* *}$ & .421 & - \\
Vocal rehearsal 10 times & $.717^{* *}$ & $.594^{*}$ & $.583^{*}$ & $.750^{* *}$ \\
\hline
\end{tabular}

REVT= Receptive \& Expressive Vocabulary Test (Kim, Hong, Kim, Jang, \& Lee, 2009). ${ }^{*} p<.05,{ }^{* *} p<.001$.

류를 가장 많이 보였으며 비관련 오류, 음절 오류, 왜곡 순으로 오류 가 나타났고 무반응은 나타나지 않았다. 외현적 시연 10 회 조건에 서는 음운 오류를 가장 많이 보였으며 그 다음으로 비관련 오류가 나타났고 음절 오류, 왜곡, 무반응은 나타나지 않았다.

\section{언어발달지연 아동과 일반 아동의 어휘력과 외현적 시연 조건에 대한 비단어 산출 수행력 간 상관관계}

언어발달지연 아동 집단의 어휘력과 외현적 시연 조건에 대한

비단어 산출 수행력 간 상관관계

언어발달지연 아동 집단에서 수용 및 표현어휘력과 외현적 시연 조건에 대한 비단어 산출 수행력 사이에 유의한 상관관계가 나타 나는지 살펴보기 위해 Pearson 적률상관계수를 측정하였다(Table
Table 4. Correlation between variables of children with normal language

\begin{tabular}{lcccc}
\hline & REVT-R & REVT-E & $\begin{array}{c}\text { Rehearsal } \\
\text { suppression }\end{array}$ & $\begin{array}{c}\text { Vocal } \\
\text { rehearsal } \\
5 \text { times }\end{array}$ \\
\hline REVT-E & $.786^{* *}$ & - & - & - \\
Rehearsal suppression & $.601^{*}$ & $.679^{* *}$ & - & - \\
Vocal rehearsal 5 times & .327 & .411 & .210 & - \\
Vocal rehearsal 10 times & $.489^{*}$ & .367 & .268 & .056 \\
\hline
\end{tabular}

REVT = Receptive \& Expressive Vocabulary Test (Kim, Hong, Kim, Jang, \& Lee, 2009). ${ }^{*} p<.05,{ }^{* *} p<.001$.

3). 그 결과, 수용어휘력은 시연 억제 조건의 수행력 $(r=.489, p<.05)$, 외현적 시연 5 회 조건의 수행력( $r=.619, p<.01)$, 외현적 시연 10 회 조건의 수행력 $(r=.717, p<.01)$ 과 유의한 상관을 보였다. 또한 표현 어휘력은 시연 억제 조건의 수행력과 유의한 상관을 보이지 않았으 나, 외현적 시연 5 회 조건의 수행력 $(r=.661, p<.01)$, 외현적 시연 10 회 조건의 수행력 $(r=.594, p<.05)$ 과 유의한 상관을 보였다.

일반 아동 집단의 어휘력과 외현적 시연 조건에 대한 비단어 산출 수행력 간 상관관계

일반 아동 집단에서 수용 및 표현어휘력과 외현적 시연 조건에 대한 비단어 산출 수행력 사이에 유의한 상관관계가 나타나는지 살펴보기 위해 Pearson 적률상관계수를 측정하였다(Table 4). 그 
결과, 수용어휘력은 외현적 시연 5 회 조건의 수행력과 유의한 상관 을 보이지 않으나, 시연 억제 조건의 수행력 $(r=.601, p<.05)$, 외현적 시연 10 회 조건의 수행력 $(r=.489, p<.05)$ 과 유의한 상관을 보였다. 또한 표현어휘력은 외현적 시연 5 회 조건의 수행력과 외현적 시연 10 회 조건의 수행력과 유의한 상관을 보이지 않으나, 시연 억제 조 건의 수행력 $(r=.679, p<.01)$ 과 유의한 상관을 보였다.

\section{논의 및 결론}

본 연구는 언어발달지연 아동 집단과 일반 아동 집단의 외현적 시연 조건에 대한 비단어 산출 수행력을 비교하여 집단 간 음운 단 기기억 능력의 차이를 알아보고 어휘력과 비단어 산출 수행력의 상관관계를 살펴보았다. 그 결과, 언어발달지연 아동 집단은 일반 아동 집단에 비해 시연 억제 조건과 외현적 시연 10 회 조건에서 유 의하게 낮은 비단어 산출 수행력을 보였다. 또한 비단어 산출 시 발 생한 오류유형을 비교한 결과, 언어발달지연 아동 집단은 시연 여 부에 따라 비단어 산출에서 질적인 차이가 발생한 반면 일반 아동 집단은 비단어 산출에서 시연 조건의 영향을 상대적으로 적게 받 았다. 그리고 언어발달지연 아동 집단에서 수용어휘력은 모든 조건 에 대한 비단어 산출 수행력과 상관을 보였고 표현어휘력은 외현적 시연을 실시한 조건에 대한 비단어 산출 수행력과 상관을 보였다. 일반 아동 집단에서 수용어휘력은 시연 억제와 외현적 시연 10 회 조건에 대한 비단어 산출 수행력과 상관을 보였고 표현어휘력은 시 연 억제 조건에 대한 비단어 산출 수행력과 상관을 보였다.

언어발달지연 아동 집단이 일반 아동 집단에 비해 모든 외현적 시연 조건에서 더 낮은 비단어 산출 수행력을 보인 결과는 언어발 달지연 아동이 새로운 단어의 음운 순서를 유지하면서 그 단어의 음운표상과 조음 패턴의 연결을 파악하는 능력이 부족하다는 연 구결과(Evans, Alibali, \& McNeil, 2001)를 지지한다. 따라서 이와 같은 음운 단기기억 능력을 필요로 하는 비단어 따라 말하기에 어 려움을 보인다는 사실을 알 수 있다. 다음으로 집단 내 외현적 시연 조건에 대한 비단어 산출 수행력에서 시연 억제 조건보다 외현적 시연을 실시한 조건에서 유의하게 높은 비단어 산출 수행력이 나타 나 외현적 시연의 횟수가 어떠하든 외현적 시연을 실시했을 경우가 시연을 하지 않는 경우보다 음운 단기기억 능력에 긍정적인 영향을 준다는 것을 추측할 수 있다. 이는 시연을 통하여 음운 정보의 삭제 를 방지하고 음운 정보를 촉진시킬 수 있다는 선행연구의 결과와 일치한다(Hickok \& Poeppel, 2000; Loomes, Starmer, \& Sugden, 2008). 나아가 외현적 시연 조건에 대한 언어발달지연 아동 집단과 일반 아동 집단의 비단어 산출 수행력에서 유의한 차이가 나타났
다. 다시 말해 두 그룹의 외현적 시연 5 회 조건의 수행력은 일반 아 동이 조금 높으나 큰 차이가 없는 것에 비하여 시연 억제 조건과 외 현적 시연 10 회 조건에 대한 수행력은 그룹 간 차이가 유의하게 컸 다. 시연 억제 조건의 비단어 수행력 차이는 일반 아동에 비하여 언 어발달지연 아동이 시연 억제의 방해를 크게 받는다는 사실을 의 미한다. 이와 같은 결과는 일반 아동이 억제 조건에서 음운표상을 유지할 수 있는 능력을 가지고 있는 것에 비하여 언어발달지연 아동 은 음운 정보를 유지하는 능력이 부족하다고 밝힌 Fatzer와 Roebers (2012)의 연구결과와 일치한다.

또한 외현적 시연 10 회 조건에서 일반 아동과 언어발달지연 아동 의 수행력 차이는 일반 아동의 수행력이 외현적 시연 5 회 조건보다 10 회 조건에서 미묘하게 증가하였고 언어발달지연 아동의 수행력 이 외현적 시연 5 회 조건보다 10 회 조건에서 감소한 결과로 보인다. 비록 수행력이 천정 효과(ceiling effect)로 인해 유의한 차이가 발생 하지는 않았으나 언어발달지연 아동이 시연 횟수가 증가함에 따라 수행력 감소를 보인 것은 눈여겨볼 만하다. 두 그룹 모두 외현적 시 연의 횟수가 증가할수록 수행력이 증가할 것이라고 예상했으나 언 어발달지연 아동의 경우 오히려 외현적 시연의 횟수가 증가했을 때 수행력이 약간 감소하였고 이로 인해 외현적 시연 10 회 조건에서 일 반 아동의 수행력과 유의한 차이가 발생하였다. 이러한 결과는 시 연 속도 및 횟수의 증가가 음운 단기기억 능력을 높여준다는 연구 결과(Caplan, Rochon, \& Waters, 1992)가 시연을 스스로 통제 가 능하고 음운 단기기억에 결함이 없는 일반 아동에게는 적용 가능 하나 얼어발달지연 아동에게서는 그러한 결과를 적용하기 어렵다 는 사실을 알 수 있다. 즉, 많은 시연 과정이 언어발달지연 아동에게 오히려 청각 자극의 정보 유지를 방해하고 집중력을 흐리는 요소 가 된 것으로 생각되며, 시연의 횟수가 항상 기억의 파지를 촉진하 는 것은 아니라고 주장한 Wessells (1982)의 연구와 일치한다.

외현적 시연 조건에 대한 비단어 산출 수행력의 오류유형에서 언 어발달지연 아동은 시연 억제 조건에서 음절 구조 및 음절 길이의 변화와 관련된 오류를 많이 보였지만 외현적 시연을 실시할 경우 경미한 수준의 음운 오류를 많이 보였고 일반 아동은 모든 조건에 서 동일하게 경미한 수준의 음운 오류를 보였다. 이러한 결과를 통 해 외현적 시연이 음운 단기기억에 긍정적인 효과를 준다는 것과 언어발달지연 아동이 일반 아동에 비해 음운 단기기억 능력이 낮 아 시연 조건에 따라 음운 정보를 저장하는 능력에서 질적인 차이 가 발생한다는 것을 추측할 수 있다. 이는 시연이 음운 단기기억 능 력을 촉진하기에 용이하고 적절한 방법이라는 Turley-Ames와 Whitfield (2003)의 연구결과를 지지한다.

비단어 산출력과 어휘력의 상관관계를 살펴보면 언어발달지연 
아동의 경우 비록 표현어휘력과 시연 억제 조건의 비단어 산출 수 행력은 낮은 상관을 보였지만 그 외의 외현적 시연 조건에 대한 비 단어 산출 수행력과 높은 상관을 보였다. 이를 통해 시연의 실시 여 부와 관계없이 언어발달지연 아동의 비단어 산출 능력은 수용 및 표현어휘력과 관련이 있으며, 비단어 산출 능력이 곧 음운 단기기 억 능력이라고 보았을 때 어휘력과음운 단기기억 사이에 밀접한 연 관이 있음을 뜻한다. 이러한 연관성과 관련하여 Montgomery (2002) 도 학령전기 단순언어장애 아동의 어휘 학습 능력과 음운 작업기 억 사이의 밀접한 연관성을 보고한 바 있다. 일반 아동의 경우 수용 및 표현어휘력이 시연 억제 조건에 대한 비단어 산출 수행력과 높 은 상관을 보일 뿐, 그 외의 조건에서는 낮은 상관을 보였다. 이는 일 반 아동의 수용어휘력과 비단어 따라 말하기 수행력의 높은 상관 을 밝힌 선행연구(Lee, 2010)의 결과와 일치하지 않는 것으로 여겨 질 수 있다. 하지만 본 연구에서 외현적 시연을 실행한 경우, 일반 아동의 비단어 산출 수행력이 대부분 비슷하게 높아 상관이 나타 나기에는 무리가 있었던 것으로 예상된다. 때문에 시연 억제 조건에 서 일반 아동이 음운 단기기억 능력에 큰 방해를 받지 않는다는 점 (Fatzer \& Roebers, 2012)을 기반으로 하여 어휘력과 시연 억제 조 건에 대한 비단어 산출 능력 사이의 높은 상관은 곧 어휘력과 비단 어 산출 능력에 어느 정도의 연관이 있다는 의미로 해석할 수 있다.

본 연구를 통해 언어발달지연 아동의 외현적 시연 조건에 대한 비단어 산출 수행력은 일반 아동에 비해 낮은 수행을 보였으며, 이 는 언어발달지연 아동의 음운 단기기억 능력이 유의하게 낮다는 사 실을 의미하는 것으로 파악되었다. 또한 외현적 시연이 음운 단기기 억 능력 향상에 긍정적인 영향을 주며, 음운 단기기억 능력과 어휘 력 사이의 연관성을 확인할 수 있었다. 이러한 결과는 음운 단기기 억이 새로운 음운 정보의 학습을 촉진하고 어휘 학습에 기여한다 는 점을 고려하였을 때(Masoura \& Gathercole, 1999) 음운단기기 억 능력은 새로운 음운 정보인 비단어를 활용하여 파악할 수 있음 을 증명한다. 더 나아가 언어발달지연 아동이 시연을 훈련하고 사 용함으로써 음운 단기기억 능력을 향상 시켜 어휘력에도 긍정적인 영향을 줄 수 있을 것으로 사료된다.

본 연구의 제한점과 후속연구를 위한 제언은 첫째, 본 연구에서 는 자극에 대한 노출 시간을 먼저 통제한 후, 외현적 시연 횟수를 조정하였기 때문에 외현적 시연 과정에서 발생하는 시연과 시연 사 이의 시간 차이가 필연적으로 발생하였다. 본 연구는 아동에게 일 정 시간 안에 훈련시킬 수 있는 적당한 시연의 횟수를 중점적으로 살펴보았으나 추후연구에서는 시연 조건을 세분화 혹은 구체화하 여 시연이 음운 단기기억에 미치는 영향을 보다 명확하게 밝힐 필 요성이 있다. 더 나아가 언어발달지연 아동의 외현적 시연뿐만 아니
라 내현적 시연을 촉진시킬 수 있는 방법에 대한 연구도 진행될 수 있을 것이다. 둘째, 본 연구에서는 외현적 시연 조건에 대한 비단어 산출의 오류유형을 살펴보았다. 하지만 각 시연 조건마다 지정된 비단어의 수가 적기 때문에 이러한 오류유형을 일반화시키는 것에 한계가 있었다. 따라서 후속 연구에서는 각 집단의 대상자 수를 충 분히 확보하거나 각 조건에 대한 비단어 수를 증가시킨 후 연구를 진행해야 할 것이다. 셋째, 본 연구에서는 아동에게 시연 조건에 대 한 설명과 연습 문제를 통해 시연을 학습시킨 후 바로 비단어 산출 과제를 실시하였다. 때문에 만약 아동이 시연 조건을 충분히 이해 하지 못했거나 시연의 실행이 불가능한 경우에는 과제 진행이 어려 웠다. 시연은 즉각적인 효과보다는 중재적인 측면으로 시연을 훈련 하고 습득하는 과정에서 관찰할 수 있는 점진적인 효과를 살펴보 는 것이 중요하므로 후속 연구에서는 지속적인 시연 훈련을 통하 여 시연의 효과와 유지 방법에 대해 다룰 것을 제안한다. 이러한 과 정을 통하여 언어에 어려움을 가진 아동들을 위한 시연 훈련 및 중 재 연구에 큰 기여를 할 수 있을 것이다.

\section{REFERENCES}

Alloway, T. P., Kerr, I., \& Langheinrich, T. (2010). The effect of articulatory suppression and manual tapping on serial recall. European Journal of Cognitive Psychology, 22, 297-305.

Alt, M. (2011). Phonological working memory impairments in children with specific language impairment: where does the problem lie? Journal of Communication Disorders, 44, 173-185.

Alt, M., \& Spaulding, T. (2011). The effect of time on word learning: an examination of decay of the memory trace and vocal rehearsal in children with and without specific language impairment. Journal of Communication Disorders, 44, 640-654.

Baddeley, A. (2000). The episodic buffer: a new component of working memory? Trends in Cognitive Sciences, 4, 417-423.

Baddeley, A. D. (1986). Working memory. London: Oxford University Press.

Baddeley, A., Gathercole, S., \& Papagno, C. (1998). The phonological loop as a language learning device. Psychological Review, 105, 158-173.

Baddeley, A., Lewis, V., \& Vallar, G. (1984). Exploring the articulatory loop. The Quarterly Journal of Experimental Psychology, 36, 233-252.

Beaton, A., Gruneberg, M., Hyde, C., Shufflebottom, A., \& Sykes, R. (2005). Facilitation of receptive and productive foreign vocabulary learning using the keyword method: the role of image quality. Memory, 13, 458-471.

Caplan, D., Rochon, E., \& Waters, G. S. (1992). Articulatory and phonologi- 
cal determinants of word length effects in span tasks. The Quarterly Journal of Experimental Psychology, 45, 177-192.

Conti-Ramsden, G., Botting, N., \& Faragher, B. (2001). Psycholinguistic markers for specific language impairment (SLI). Journal of Child Psychology and Psychiatry and Allied Disciplines, 42, 741-748.

Cowan, N. (1992). Verbal memory span and the timing of spoken recall. Journal of Memory and Language, 31, 668-684.

Cowan, N., \& Kail, R. (1996). Covert processes and their development in short-term memory. Models of short-term memory, 29-50.

Dell, G. S., Schwartz, M. F., Martin, N., Saffran, E. M., \& Gagnon, D. A. (1997). Lexical access in aphasic and nonaphasic speakers. Psychological Review, 104, 801-838.

DeMarie, D., Miller, P. H., Ferron, J., \& Cunningham, W. R. (2004). Path analysis tests of theoretical models of children's memory performance. Journal of Cognition and Development, 5, 461-492.

Ellis, N. R. (1970). Memory processes in retardates and normals. International Review of Research in Mental Retardation, 4, 1-32.

Ellis, N., \& Beaton, A. (1993). Factors affecting the learning of foreign language vocabulary: imagery keyword mediators and phonological shortterm memory. The Quarterly Journal of Experimental Psychology, 46, 533558.

Evans, J. L., Alibali, M. W., \& McNeil, N. M. (2001). Divergence of verbal expression and embodied knowledge: evidence from speech and gesture in children with specific language impairment. Language and Cognitive Processes, 16, 309-331.

Fatzer, S. T., \& Roebers, C. M. (2012). Language and executive functions: the effect of articulatory suppression on executive functioning in children. Journal of Cognition and Development, 13, 454-472.

Fletcher, K. L., \& Bray, N. W. (1996). External memory strategy use in preschool children. Merrill-Palmer Quarterly, 42, 379-396.

Gathercole, S. E., \& Adams, A. M. (1993). Phonological working memory in very young children. Developmental Psychology, 29, 770-770.

Gathercole, S. E., \& Baddeley, A. D. (1993). Phonological working memory: a critical building block for reading development and vocabulary acquisition? European Journal of Psychology of Education, 8, 259.

Henry, L. A. (1991). Development of auditory memory span: the role of rehearsal. British Journal of Developmental Psychology, 9, 493-511.

Hickok, G., \& Poeppel, D. (2000). Towards a functional neuroanatomy of speech perception. Trends in Cognitive Sciences, 4, 131-138.

Horst, J. S., \& Hout, M. C. (2016). The Novel Object and Unusual Name (NO-
UN) database: a collection of novel images for use in experimental research. Behavior Research Methods, 48, 1393-1409.

Hulme, C., Lee, G., \& Brown, G. D. (1993). Short-term memory impairments in Alzheimer-type dementia: evidence for separable impairments of articulatory rehearsal and long-term memory. Neuropsychologia, 31, 161-172.

Huttenlocher, J., \& Burke, D. (1976). Why does memory span increase with age? Cognitive Psychology, 8, 1-31.

Jeon, H. S. (1991). Short-term memory effect according to importance of life essential vocabulary and demonstration method. International Journal of Creativity \& Problem Solving, 1, 50-80.

Kan, P. F., Sadagopan, N., Janich, L., \& Andrade, M. (2014). Effects of speech practice on fast mapping in monolingual and bilingual speakers. Journal of Speech, Language, and Hearing Research, 57, 929-941.

Keeney, T. J., Cannizzo, S. R., \& Flavell, J. H. (1967). Spontaneous and induced verbal rehearsal in a recall task. Child Development, 38, 953-966.

Kim, H., \& Yim, D. (2012). The performance on working memory span task in children with high-function autism. Communication Sciences \& Disorders, $17,451-465$.

Kim, O. H. (1997). Effects of continuity and interval time in verbal rehearsals on recall. Early Childhood Education Research \& Review, 1, 239-262.

Kim, Y. G. (2012). The effects of the memory strategy for the recall memory and the implication for occupational therapy. Korean Society of Cognitive Rehabilitation, 1, 5-21.

Kim, Y. T., Hong, G. H., Kim, K. H., Jang, H. S., \& Lee, J. Y. (2009). Receptive \& expressive vocabulary test (REVT). Seoul: Seoul Community Rehabilitation Center.

Lee, H. J. (2010). The influences of number of syllables and wordlikeness on 3to 5-year-old Korean-English bilingual children's nonword repetition (Master's thesis). Ewha University, Seoul, Korea.

Leonard, L. (1998). Children with specific language impairment. Cambridge, MA: MIT Press.

Loomes, G., Starmer, C., \& Sugden, R. (1989). Preference reversal: information-processing effect or rational non-transitive choice? The Economic Journal, 99, 140-151.

Martin, K. I., \& Ellis, N. C. (2012). The roles of phonological short-term memory and working memory in L2 grammar and vocabulary learning. Studies in Second Language Acquisition, 34, 379-413.

Masoura, E. V., \& Gathercole, S. E. (1999). Phonological short-term memory and foreign language learning. International Journal of Psychology, 34, 383388. 
Montgomery, J. W. (2002). Understanding the language difficulties of children with specific language impairments: does verbal working memory matter? American Journal of Speech-Language Pathology, 11, 77-91.

Montgomery, J. W., \& Evans, J. L. (2009). Complex sentence comprehension and working memory in children with specific language impairment. Journal of Speech, Language, and Hearing Research, 52, 269-288.

Moon, S. B., \& Byun, C. J. (2003). Korean-Kaufman Assessment Battery for Children (K-ABC). Seoul: Hakjisa.

Oh, D. Y., \& Yim, D. (2013). Non-word repetition and sentence repetition performance in 2-3 years old late talkers and normal children. Communication Sciences \& Disorders, 18, 277-287.

Oxley, J., \& Norris, J. (2000). Children's use of memory strategies: relevance to voice output communication aid use. Augmentative and Alternative Communication, 16, 79-94.

Papagno, C., Valentine, T., \& Baddeley, A. (1991). Phonological short-term memory and foreign-language vocabulary learning. Journal of Memory and Language, 30, 331-347.

Park, Y. A., \& Choi, K. S. (2007). Developmental changes in children's use of memory strategies. Korean Journal of Developmental Psychology, 20, 59-75.

Rispens, J., \& Baker, A. (2012). Nonword repetition: the relative contributions of phonological short-term memory and phonological representations in children with language and reading impairment. Journal of Speech, Language, and Hearing Research, 55, 683-694.
Sadagopan, N., \& Smith, A. (2008). Developmental changes in the effects of utterance length and complexity on speech movement variability. Journal of Speech, Language, and Hearing Research, 51, 1138-1151.

Soto, D., \& Humphreys, G. W. (2008). Stressing the mind: the effect of cognitive load and articulatory suppression on attentional guidance from working memory. Attention, Perception, \& Psychophysics, 70, 924-934.

Stanovich, K. E., \& Siegel, L. S. (1994). Phenotypic performance profile of children with reading disabilities: a regression-based test of the phonological-core variable-difference model. Journal of Educational Psychology, 86, 24-53.

Swanson, H. L., \& Berninger, V. (1995). The role of working memory in skilled and less skilled readers' comprehension. Intelligence, 21, 83-108.

Sweet, L. H., Vanderhill, S. D., Jerskey, B. A., Gordon, N. M., Paul, R. H., \& Cohen, R. A. (2010). Subvocal articulatory rehearsal during verbal working memory in multiple sclerosis. Neurocase, 16, 418-425.

Torgesen, J., \& Goldman, T. (1977). Verbal rehearsal and short-term memory in reading-disabled children. Child Development, 48, 56-60.

Turley-Ames, K. J., \& Whitfield, M. M. (2003). Strategy training and working memory task performance. Journal of Memory and Language, 49, 446-468. Wessells, M. G. (1982). Cognitive psychology. New York, NY: Harper \& Raw. Yim, D., Yang, Y., \& Kim, S. (2015). Domain-specific working memory performance in children with and without specific language impairment. Communication Sciences \& Disorders, 20, 13-23. 
외현적 시연 과제 기록지

\begin{tabular}{|c|c|c|c|}
\hline \multirow{2}{*}{ 아동명(성별) } & & 생년월일(생활연령) & \\
\cline { 3 - 5 } & & 검사일 & \\
\hline 검사 유형 & A형 $\quad$ B형 $\quad$ C형 \\
\hline
\end{tabular}

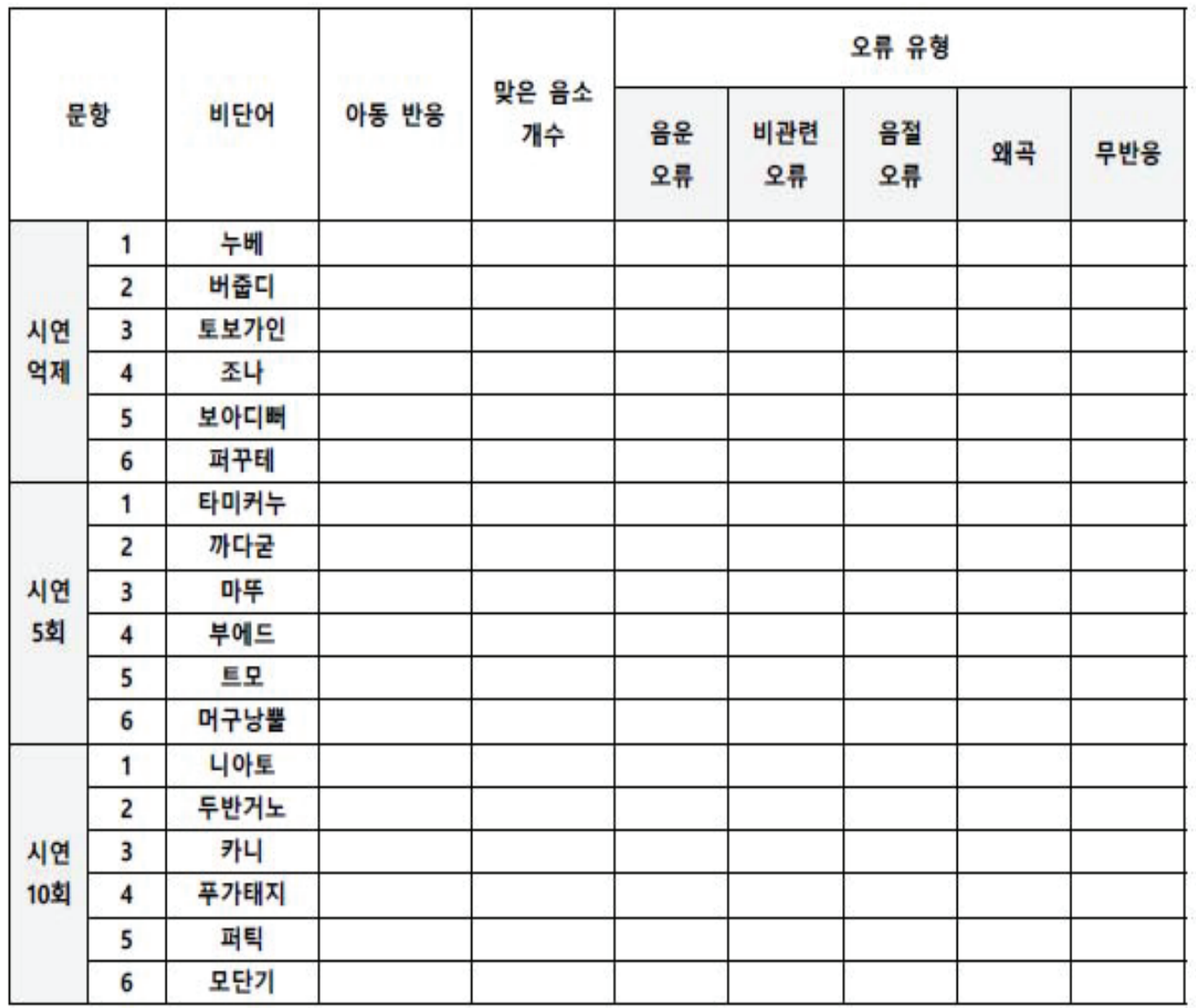


Appendix 2. 추상적 그림의 NOUN Database (Horst \& Hout, 2016)

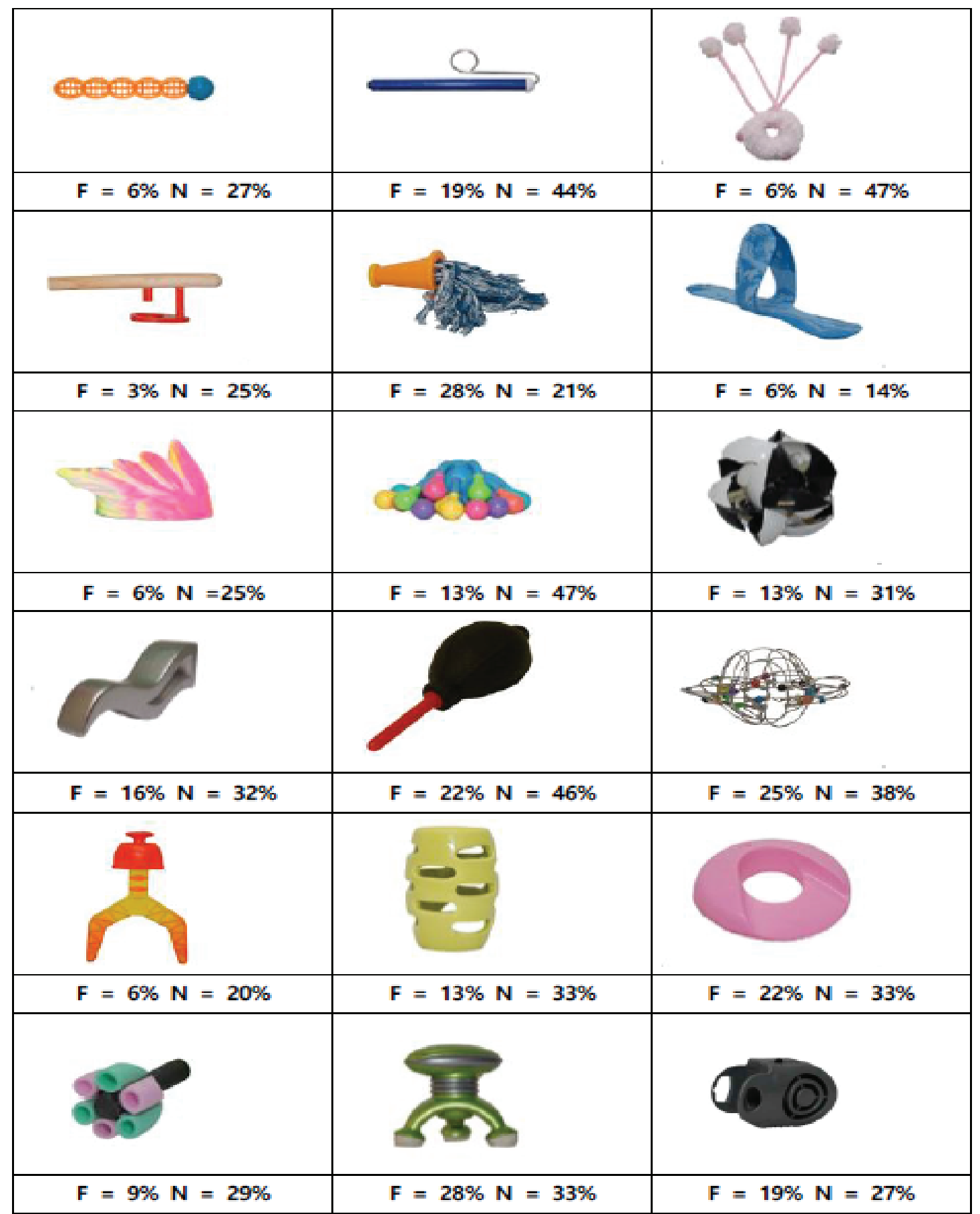




\section{국문초록}

\section{언어발달지연 아동의 외현적 시연(vocal rehearsal) 조건에 대한 비단어 산출 수행력} 이슬기 · 임동선

이화여자대학교 대학원 언어병리학과

배경 및 목적: 음운 정보에 대한 능동적인 시연은 음운 단기기억 능력을 촉진하며 어휘 학습에도 긍정적인 영향을 미친다. 그러므로 본 연구는 시연 여부와 횟수의 조절이 용이한 외현적 시연을 조건화하여 음운 정보 산출 능력을 살펴보고 언어발달지연 아동의 음운 단기 기억 능력을 향상시킬 수 있는 방안을 모색하고자 하였다. 이를 통해 언어발달지연 아동의 음운 단기기억 결함을 해결하기 위한 적절한 시연 방법과 정도를 파악하는데 도움이 되고자 하였다. 방법: 5-7세 언어발달지연 아동 17명, 일반 아동 17명을 대상으로 외현적 시연 조건(시연 억제, 외현적 시연 5 회, 외현적 시연 10 회)에 대한 비단어 산출 과제를 실시하여 비단어 산출 수행력을 비교분석 하였다. 결과: 외현적 시연 조건에 대한 집단 간 비단어 산출 수행력의 차이가 통계적으로 유의미하게 나타났고 언어발달지연 아동은 시연 조건에 따 라 오류유형의 변화가 나타났다. 또한 외현적 시연 조건에 대한 비단어 산출 수행력은 어휘력과 연관성이 있었다. 논의 및 결론: 외현적 시연은 비단어 산출 수행력 향상에 긍정적인 영향을 주며, 외현적 시연 조건에 대한 비단어 산출 수행력을 통해 언어발달지연 아동이 일반 아동에 비해 음운 단기기억 능력이 낮다는 사실을 파악할 수 있었다. 따라서 언어발달지연 아동에게 시연을 훈련시키고 아동이 시 연을 사용함으로써 음운 단기기억 능력은 향상될 수 있으며 어휘력에도 긍정적인 영향을 줄 것으로 예상된다.

핵심어: 언어발달지연. 외현적 시연, 비단어, 음운 단기기억

본 논문은 제 1 저자의 석사학위논문을 요약한 것임.

\section{참고문헌}

김영근(2012). 기억전략이 회상기억에 미치는 영향과 작업치료 함의: 범주화와 시연전략중심으로. 대한인지재활학회, 1, 5-21.

김영태, 홍경훈, 김경희, 장혜성, 이주연(2009). 수용·표현어휘력검사(REVT). 서울: 서울장애인종합복지관.

김옥향(1997). 언어적 사연과제에서 연속 및 휴지조건이 회상기억에 미치는 효과. 유아교육학논집, 1, 239-262.

문수백, 변창진(2003). K-ABC 교육·심리측정도구(Korean-Kaufman assessment battery for children). 서울: 학지사.

박영아, 최경숙(2007). 아동의 연령에 따른 기억책략 사용의 효율성 분석. 한국심리학회지: 발달, 20, 59-75.

오다연, 임동선(2013). 2-3세 말 늦은 아동과 정상 아동의 비단어 따라말하기와 문장 따라말하기 수행 능력. 언어청각장애연구, 18, 277-287.

이현정(2010). 음절길이와 단어유사성이 3-5 세 한국어-영어 이중언어아동의 비단어 따라말하기 수행에 미치는 영향. 이화여자대학교 대학원 석사 학위논문. 